\title{
Impact of agrocenoses on the populations of small mammals of recreational pine forests in the Tom River Valley
}

\author{
Ekaterina Luchnikova ${ }^{1, *}$, Vadim Ilyashenko ${ }^{1}$, Natalya Teplova ${ }^{1}$, Alexander Kovalevsky ${ }^{1,2}$, \\ and Kirill Zubko ${ }^{1}$ \\ ${ }^{1}$ Kemerovo State University, 6, Krasnaya str., 650000, Kemerovo, Russia \\ ${ }^{2}$ Kuzbass State Agricultural Academy, 5, Markovtseva str., 650056, Kemerovo, Russia
}

\begin{abstract}
The paper is devoted to studying the influence of agricultural land on the formation of small mammal communities in the pine forests of the Tom River Valley. For the analysis, we took sites of natural and artificial pine forests of different areas experiencing various anthropogenic pressures. It was revealed that species composition, species richness and species diversity of small mammalian communities depend on a whole complex of factors. Thus, the population of right-bank forests is largely determined by the influence of mountain-taiga complexes of mammals in the adjacent territories. Cutting down taiga forests and using the vacant spaces for agricultural purposes lead to the introduction of species that prefer open biotopes to the initial community. A correlation was found between the size of the pine forest and its resistance to invasive species. The creation of artificial pine forests in the forest-steppe does not lead to the formation of typical forest communities of small mammals, due to their limited ability to resettle. Quite extensive, but to varying degrees isolated natural and artificial pine forests within the city and along the boundaries of the city are unique ecological "islands" that play a significant role in maintaining the diversity of the urban fauna of mammals.
\end{abstract}

\section{Introduction}

Currently, the anthropogenic transformation of landscapes and the reduction of biological diversity are some of the most significant environmental problems.

In accordance with the concept of sustainable development, all living organisms on Earth are not just components of a biosphere, but also important links in food chains. The conservation and restoration of biological diversity is possible not only within the framework of conservation of undisturbed natural landscapes but also within the framework of competent forestry management, including the organization of recreational forest park zones. In Western Siberia in the suburban areas, the most favorable animal habitats are preserved forest parks, especially pine forests in river valleys. As a rule, such forest parks are partially or completely delimited from natural forests by agro landscapes: arable lands or proprietary crofts. According to the scientific data during the development of suburban

* Corresponding author: lut@yandex.ru 
infrastructure, specific conditions are formed that lead to the appearance of zoocenoses with low species diversity and a high proportion of anthropophilic and synanthropic species, some of which are absent in the indigenous fauna $[1,2,3]$.

The valley of the Tom River is located on the border of two physiographic regions of the Kuznetsk-Salair mountain area: the right-bank part is located in the foothills of the Kuznetsk Alatau, and the left-bank part is in the Kuznetsk Depression. According to phytocenological features, the left-bank part is a birch forest-steppe. On the right bank of the Tom River, pine forests are widespread, interspersed with agricultural land, as well as meadows, birch-aspen forests, and plots of dark coniferous taiga. These forests vary in area, and the degree of anthropogenic impact; their vegetation is to varying degrees affected by adjacent agricultural land. Meadow, ruderal, and cultivated plants from adjacent agrocenoses penetrate to forest communities. All areas of pine forests within the river valley are located on elevated banks, which contributes to the xerophytization of habitats [4].

For analysis, we selected several sites of pine forests of various origin, occupied area, and type of the anthropogenic impact. The focus was on urban and suburban forests.

There are several pine forests, which occupy quite significant areas within the boundaries of the city of Kemerovo. On the right bank, adjacent to the river, there is a natural old fern-forb pine forest with an area of about 400 hectares (the Rudnik Bor). It is surrounded on two sides by urban development and is separated from its peripheral part by a highway. The peripheral part occupies about 50 hectares and is surrounded by agricultural land.

In the left-bank part of the city and the suburbs, there is a scattered middle-aged pine forest with an area of about 30-40 hectares (the Jagunovsky Bor). This is a forest of artificial origin. It borders with both urban development and agricultural land (arable land, pastures).

All urban pine forests are constantly experiencing intense year-round anthropogenic impact.

Podiakovsky and Pisany pine forests are located on the right bank of the Tom River. They are the remains of natural pine forests, and are 30 and $60 \mathrm{~km}$ away from the city, respectively. These suburban forests border mainly with the massifs of aspen-fir forests, and, to a lesser extent, with arable land and hayfields. Both of these forests experience seasonal anthropogenic impact (from spring to mid-autumn).

Pine forest Gorodok is a small remnant of the natural forest with an area of 2 hectares, which is located among the secondary-growth birch forests and agricultural land. The anthropogenic impact on it is relatively low and occurs only in the summer.

As a control site, we have chosen Lachinovo pine forest, located on the left bank of the Tom River. It is $140 \mathrm{~km}$ upstream from the city, has an area of about 3 hectares, and is surrounded by fir-aspen forests. This forest is not subject to anthropogenic impact.

We have selected small mammals as an object of biomonitoring. They form the basis of theriofauna of any locality. The number of species, structure and spatial heterogeneity of their communities are those markers that allow us to evaluate the effects of anthropogenic impact on natural complexes by zoological methods [5]. Of particular interest are the responsiveness of rodents to changes in life conditions, manifested particularly in fluctuations in their numbers and the transformation of the hierarchical structure of communities [6-10].

Based on this, we have set the tasks to study small mammalian communities in natural and artificial pine forests of various types, as well as to assess the influence of adjacent agrocenoses on the population of small mammals of recreational pine forests in the Tom River Valley. 


\section{Materials and Methods}

Small mammals were counted according to the standard method: by using 50-meter catching grooves with 5 cylindrical pitfalls, in the spring-autumn period of 1992-2017. Despite its high complexity, this method has an advantage over capturing with bait because it has no selectivity. The absence of selectivity in captures allows us to obtain the results that most accurately represent the ratio of the species of small mammals in the studied community. A total of 1897 small mammals were captured during the study period. The results of capturing are presented in Table 1.

Table 1. The captured species of small mammals in the pine forests of the Tom River Valley in 19922017 and their percentage proportions.

\begin{tabular}{|c|c|c|c|c|c|c|c|}
\hline & \multicolumn{7}{|c|}{ Pine forests } \\
\hline & 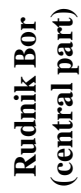 & 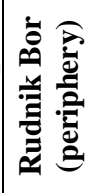 & 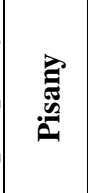 & 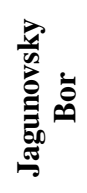 & 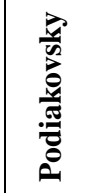 & 冚 & 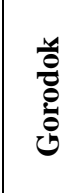 \\
\hline Total amount of captured species & 11 & 15 & 13 & 10 & 15 & 20 & 17 \\
\hline Total amount of captured small mammals & 65 & 119 & 113 & 423 & 112 & 736 & 329 \\
\hline Species & \multicolumn{7}{|c|}{ Proportion of captured species (in \%) } \\
\hline $\begin{array}{l}\text { Siberian white-toothed shrew Crocidura sibirica } \\
\text { Dukelsky. } 1930\end{array}$ & - & - & - & - & - & 0.82 & 0.61 \\
\hline Pigmy shrew Sorex minutus Linnaeus. 1766 & 12.31 & 14.29 & 10.62 & 14.42 & 8.93 & 9.65 & 5.47 \\
\hline Laxmann's shrew Sorex caecutiens Laxmann. 1788 & 9.23 & 4.20 & 23.89 & - & 21.43 & 13.32 & 6.99 \\
\hline Flat-skulled shrew Sorex roboratus Hollister. 1913 & 3.08 & 2.52 & 9.73 & - & 7.14 & 1.49 & 6.99 \\
\hline Taiga shrew Sorex isodon Turov. 1924 & 10.77 & - & 13.27 & - & 19.64 & 13.32 & 0.91 \\
\hline Common shrew Sorex araneus Linnaeus. 1758 & 23.08 & 23.53 & 15.04 & 40.19 & 16.07 & 18.21 & 20.97 \\
\hline Tundra shrew Sorex tundrensis Merriam. 1900 & 7.69 & 14.29 & 7.96 & 2.36 & 0.89 & 2.31 & 6.08 \\
\hline Water shrex Neomys fodiens (Pennant. 1771) & - & - & - & - & - & 0.54 & - \\
\hline $\begin{array}{l}\text { Northern birch mouse Sicista betulina (Pallas. } \\
\text { 1779) }\end{array}$ & - & - & 7.96 & - & 4.46 & 4.35 & 1.52 \\
\hline Bank-vole Myodes glareolus (Schreber. 1780) & 9.23 & 5.04 & - & - & 2.68 & 3.26 & 1.22 \\
\hline $\begin{array}{l}\text { Northern red-backed vole Myodes rutilus (Pallas. } \\
\text { 1779) }\end{array}$ & 10.77 & 3.36 & 0.88 & 1.65 & 4.46 & 3.26 & 0.91 \\
\hline $\begin{array}{l}\text { Grey red-backed vole Myodes rufocanus } \\
\text { (Sundevall. 1846) }\end{array}$ & - & - & - & - & 2.68 & 2.17 & - \\
\hline Water vole Arvicola amphibious (Linnaeus. 1758) & - & - & - & 0.24 & - & 0.14 & 0.30 \\
\hline Root vole Microtus oeconom & - & 0.84 & 1.77 & - & 1.79 & 6.93 & 7.60 \\
\hline Comman vole Microtus arvalis (Pallas. 1778) & 3.08 & 13.45 & - & 34.04 & 1.79 & 0.41 & 6.38 \\
\hline Field vole Microtus agrestis (Linnaeus. 1761) & - & 2.52 & 0.88 & - & 2.68 & 1.90 & 4.56 \\
\hline $\begin{array}{l}\text { Narrow-headed vole Microtus gregalis (Pallas. } \\
\text { 1779) }\end{array}$ & - & 1.68 & 1.77 & 1.42 & - & 0.14 & 0.91 \\
\hline $\begin{array}{l}\text { Korean field mouse Apodemus peninsulae } \\
\text { (Thomas. 1907) }\end{array}$ & 7.69 & 1.68 & 2.65 & - & 4.46 & 11.14 & - \\
\hline $\begin{array}{l}\text { Striped field mouse Apodemus agrarius (Pallas. } \\
\text { 1771) }\end{array}$ & 3.08 & 6.72 & 3.54 & 3.31 & 0.89 & 4.35 & 27.05 \\
\hline House mouse Mus musculus Linnaeus. 1758 & - & 2.52 & - & 0.47 & - & - & - \\
\hline Harvest mouse Micromys minutus (Pallas. 1771) & - & 3.36 & - & 1.89 & - & 2.31 & 1.52 \\
\hline
\end{tabular}

Relative numbers of animals were calculated as the number of captured animals in ratio to 100 cylinder-days. To assess species diversity, we used the Simpson polydominance index. The community similarity was estimated by species proportion with the help of the Czekanowski-Sørensen index $[11,12]$. 


\section{Results and Discussion}

The fauna of small mammals of the Tom River Valley, in which all the studied sites are located, has 22 species of small mammals, 9 of which belong to the Lipotypha order, and the remaining 13 belong to the Rodentia order [13]. The difference in the landscapes of the right and left banks leads to the formation of two main complexes. A taiga complex was formed on the right bank with the prevalence of shrews: taiga shrew, and Laxmann's shrew; and rodents: northern red-backed vole, grey red-backed vole, and Korean field mouse. The left-bank part of the valley is mainly occupied by a forest-steppe with small isolated areas of coniferous forests. Here, among the shrews, the common shrews, dominates, and among rodents, the striped field mice and the gray voles of the genus Microtus are dominant.

The root voles and the water shrews, as well as, in some years, the water voles play an important role in the coastal part of the Tom River Valley. These species can reach significant numbers, but outside the floodplain (including pine forests), their abundance decreases sharply.

In total, 21 species of small mammals were recorded in the pine forests, 16 of which live directly within the city boundaries (see Table 1). Shrews are very diverse among these species and represented by 6 species: common shrew, tundra shrew, Laxmann's shrew, taiga shrew, flat-skulled shrew, and pigmy shrew. Shrews of other genera: the Siberian white-toothed shrew and the water shrew were captured sporadically in studied areas of Lachinovo and Gorodok, located remotely from the city.

The following mouse-like rodents inhabit urban forests: bank-voles, narrow-headed voles, field voles, striped field mice, Korean field mice, harvest mice. It was noted that house mice, penetrates adjacent pine forests from residential areas of the city, especially from one-story suburbs, and in the autumn common voles penetrates pine forests from fields. This species is able to penetrate even into the residential area, populating outbuildings and cellars [14]. The root voles penetrates only the peripheral part of the Rudnik Bor along the moist floodplains of the creeks.

Outside the city, in the pine forests of the suburban area, the species diversity of small mammals is slightly higher. Three more species of rodents are found here: the grey redbacked vole, the northern birch mouse, and the water vole. Among the species of small mammals that were not registered in captures from urban forests, we should specially mention the grey red-backed vole, a typical inhabitant of aspen-fir forests. Only the least shrew Sorex minutissimus Zimmermann, 1780, wasn't captured anywhere in the studied areas.

In the dendrogram illustrating the faunistic similarity of the population of small mammals, the complexes of mammals of Lachinovo, Pisany, and Podiakovsky pine forests form a group of similar communities (Figure 1). The Lachinovo pine forest's community demonstrates the highest rates of species richness and diversity. It contains all captured species, except for the synanthropic house mouse. Here, species that inhabit adjacent mountain taiga landscapes and forest-steppe species are participate in the formation of communities. In the absence of an anthropogenic impact, a complex polydominant community is formed, which combines both forest and forest-steppe species of small mammals. 


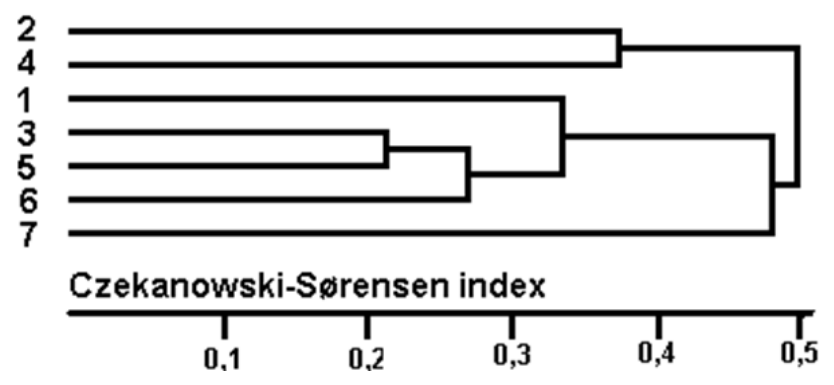

Fig. 1. Dendrogram of similarity among communities of small mammals in pine forests: 1 - Rudnik Bor (central part); 2 - Rudnik Bor (periphery); 3 - Pisany; 4 - Jagunovsky Bor; 5 - Podiakovsky; 6 Lachinovo; 7 -Gorodok.

Pisany and Podyakovo pine forests are closest to Lachinovo control site. They are very similar to each other, which is understandable, given the location and similarity of the genesis of these forests, and the similar nature of the anthropogenic influences experienced by them. Both communities are characterized by an average species richness and diversity (Figure 2, Table 1). Here, a complex of species that inhabits adjacent taiga landscapes is involved in the formation of communities. In the insectivore community, taiga species dominate, such as Laxmann's, taiga, and flat-skulled shrews. A significant part is represented by eurytopic species, namely: common, and pigmy shrews. The percentage of the tundra shrew, a typical inhabitant of open spaces, ranges from 1 to $8 \%$. Typical forest species dominate in the rodent community: Korean field mouse, grey red-backed, and northern red-backed voles. The striped field mice, a typical inhabitant of meadows and agrocenoses, penetrates only the Pisany pine forest. The presence of the root voles (mesophilic species) is associated with the presence of floodplain meadows, moist and waterlogged places that occur in narrow valleys of the tributaries of the Tom River.

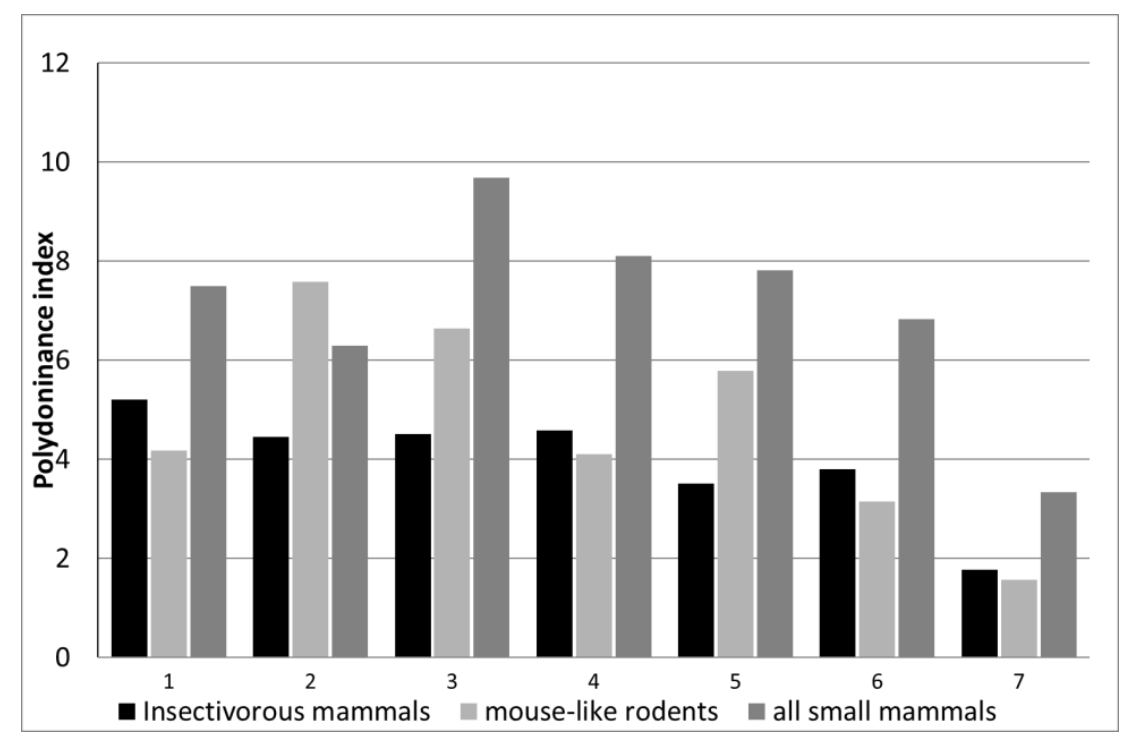

Fig. 2. Indices of species diversity of small mammals in pine forests of the Tom River Valley: Natural forests (1 - Pisany; 2 - Podiakovsky; 3 - Lachinovo; 4 - Rudnik Bor (central part)); Destroyed forests ( 5 - Rudnik Bor (periphery); 6 - Gorodok); Artificial forest (7 - JagunovskyBor).

According to the characteristics of the population of small mammals, the central part of the Rudnik Bor belongs to the same group, although it has individual features. It is 
relatively low-susceptible to the penetration of species from open sites and agrocenoses. Here we observe a typical forest community of small mammals, although somewhat depleted in species richness. Among insectivorous mammals, the eurytopic common shrews and taiga shrews, a typical inhabitant of taiga forests, dominate. Among the rodents, taiga species dominate, such as the northern red-backed vole and the Korean field mouse. The proportion of bank-voles is quite high, which in the south of Western Siberia can be considered as an indicator species of disturbed forests [11].

Even greater influence of adjacent agrocenoses is experienced by the Gorodok pine forest. Its population is characterized by the complete absence or a sharp decrease in the proportion of taiga species: the grey red-backed vole, the Korean field mouse, and the taiga shrew. In comparison with the forests mentioned above, the number of other forest species, such as the Laxmann's shrew and the northern red-backed vole, is significantly reduced here. The striped field mice, penetrating the forest from neighboring hayfields and sown fields, acquires the status of the absolute dominant among rodents. The small area of the forest does not contribute to the conservation of the indigenous complex of mammals as in the forests described above.

Similar factors have a significant impact on the community of the peripheral part of the Rudnik Bor, which also experiences a strong year-round anthropogenic impact. Eurytopic species, such as: the common and pigmy shrews, dominate among insectivores. The species of open spaces, namely the tundra shrew, penetrates here from the adjacent hay meadows. A similar situation is observed among rodents: the common voles dominates here which is a typical inhabitant of open spaces and agrocenoses. The proportion of natural forest species of rodents is sharply reduced. The combination of forest species and the introduction of open spaces and even synanthropic species into the community leads to relatively high rates of species richness and species diversity.

Artificial pine plantings of the left-bank part of the city (the Jagunovsky Bor) demonstrate the poorest biological diversity (Figures 1,2). In terms of a species structure, the population of the Jagunovsky Bor is similar to that of the forest-steppe of the Kuznetsk Depression [12]. The community of small mammals is sharply depleted; it is characterized, in contrast to the communities of right-bank forests, by a monodominant structure (Table 2, Figure 1). It is manifested in the significant predominance of two species: the common vole and the common shrew with the co-domination of the pigmy shrew. The remaining species, such as tundra shrew, striped field mouse, harvest mouse, narrow-headed, and northern redbacked voles, are significantly inferior in relative abundance to dominant species, occupying a subordinate position in the community: the proportion of them is about $2 \%$. The water voles penetrates the forest from adjacent wetted meadows not on an annual basis. Of the real synanthropic species, the house mouse is found here.

Table 2. The number and abundance of small mammals in pine forests of the left-bank part of Kemerovo.

\begin{tabular}{|l|c|c|c|c|c|c|c|c|}
\hline \multirow{2}{*}{ Species } & \multicolumn{2}{|c|}{1997} & \multicolumn{2}{c|}{1998} & \multicolumn{2}{c|}{1999} & \multicolumn{2}{c|}{2000} \\
\cline { 2 - 9 } & $\mathrm{N}^{*}$ & $\mathrm{~A}^{* *}$ & $\mathrm{~N}$ & $\mathrm{~A}$ & $\mathrm{~N}$ & $\mathrm{~A}$ & $\mathrm{~N}$ & $\mathrm{~A}$ \\
\hline S. minutus & 30 & 1.02 & 11 & 1.0 & 13 & 0.7 & 2 & 0.28 \\
\hline S. araneus & 133 & 4.5 & 12 & 1.1 & 17 & 0.9 & 2 & 0.28 \\
\hline S. tundrensis & 2 & 0.07 & 1 & 0.09 & 4 & 0.2 & 3 & 0.43 \\
\hline M. rutilus & 1 & 0.003 & - & - & 4 & 0.2 & 1 & 0.14 \\
\hline M. arvalis & 84 & 2.8 & 3 & 0.3 & 33 & 1.8 & 20 & 2.86 \\
\hline M. gregalis & 4 & 0.13 & - & - & - & - & 2 & 0.28 \\
\hline A. agrarius & 8 & 0.3 & - & - & 1 & 0.06 & 4 & 0.57 \\
\hline M. minutus & 5 & 0.17 & - & - & - & - & 3 & 0.43 \\
\hline Total: & 267 & 9.1 & 27 & 2.4 & 72 & 4.0 & 37 & 5.3 \\
\hline
\end{tabular}


Where: *Number of small mammals, **Specimens per 100 cylinder-days.

However, such a hierarchical structure of the community of small mammals is rather unstable. As shown by long-term observations of S. Onishchenko [12], in certain periods it can vary significantly (Table 2). As an example, in the autumn of 1997, an outbreak of abundance of the common voles was observed, accompanied by expressed migration processes that led to migrants settling in the vicinity of the left-bank part of Kemerovo in the end of summer. Then, in 1998-1999, there was a decrease of abundance of most species. Among the subordinate species, striped field mouse, harvest mouse, northern red-backed vole, and narrow-headed vole, were not registered in captures, which led to an even greater depletion of the species composition of the community.

Rather extensive, but to somewhat isolated natural and artificial pine forests within the city limits are unique ecological "islands" that play a significant role in maintaining the diversity of the urban fauna of mammals [15].

Thus, the community of small mammals of pine forests represents a dynamic structure. Its species composition, species richness and species diversity depend on a large complex of factors. The population of right-bank forests is determined by the influence of mountaintaiga complexes of mammals in the adjacent territories. Cutting down of the taiga forests and using the vacant spaces for agricultural purposes lead to the introduction of species that prefer open biotopes to the original communities. The smaller the forest area is, the greater is the impact of adjacent communities.

An informative indicator of the influence of adjacent agrocenoses is the ratio of the pairs of common/taiga shrews (Figure 3) and the Korean field/striped field mice (Figure 4). In the disturbed forests surrounded by agricultural landscapes, taiga shrews disappear, though, in undisturbed forest communities it plays the role of a dominant or codominant. A similar situation is observed in rodents: the striped field mice penetrate from agrocenoses and replace or completely displace the Korean field mice.

The creation of artificial pine plantations in open areas, including as part of revegetation measures, does not lead to the formation of typical forest communities of small mammals in them, due to their limited ability to resettle.

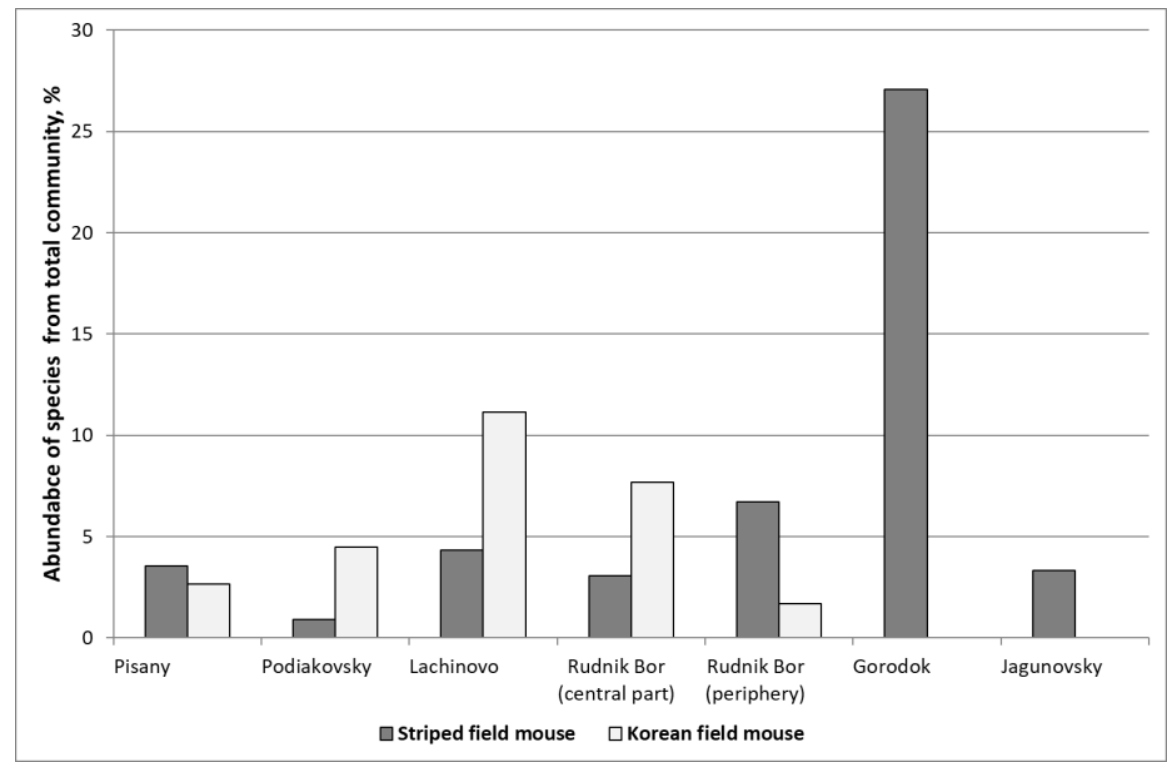

Fig. 3. The ratio of abundance indices of striped field and Korean field mice in pine forests of the Tom River Valley: Natural forests (Pisany, Podiakovsky, Lachinovo, Rudnik Bor (central part)); Destroyed forests (Rudnik Bor (periphery), Gorodok); Artificial forest (JagunovskyBor). 


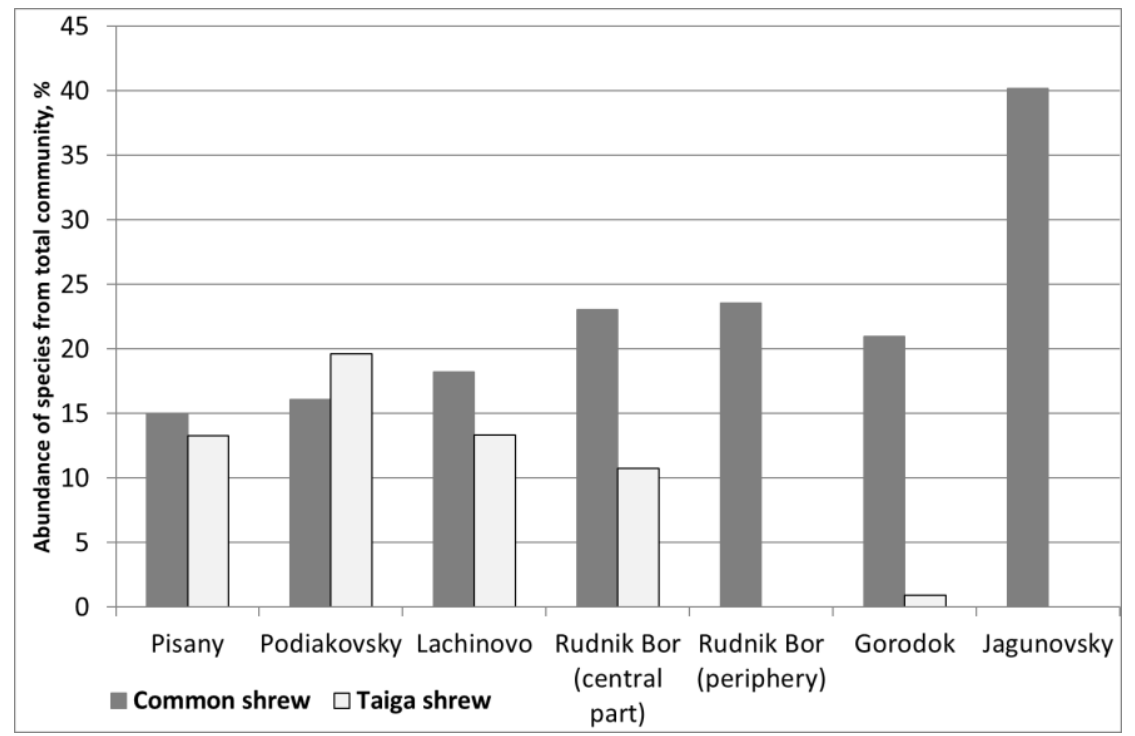

Fig. 4. The ratio of the abundance of common and taiga shrews in different parts of the Tom River Valley: Natural forests (Pisany, Podiakovsky, Lachinovo, Rudnik Bor (central part)); Destroyed forests (Rudnik Bor (periphery), Gorodok); Artificial forest (JagunovskyBor).

\section{Acknowledgements}

The research was funded by the Russian Foundation for Basic Research (Project No. 20-44420008).

\section{References}

1. E. Kalies, B. Dickson, C. Chambers, W. Covington, Ecological Applications 22(1), 204-217 (2012) doi: 10.2307/41416753

2. T. Sullivan, D. Sullivan, P. Lindgren, D. Ransome, Journal of Mammalogy 93(6), 1456-1468 (2012) doi: 10.2307/23321353

3. M. Lantschner, V. Rush, J. Hayes, Mammalia 75, 249-255 (2011) doi: 10.1515/MAMM.2011.031

4. R. Sollmanna, A. White, B. Gardner, P. Manley, Mammalian Biology 80, 247-254 (2015) doi: 10.1016/j.mambio.2015.03.002

5. V. Ilyashenko, E. Luchnikova, N. Skalon, Bulletin of KemSU 4-3 (64), 25-30 (2015)

6. M. Niedziałkowska, J. Kończak, S. Czarnomska, B. Jędrzejewska, Ecoscience 17(1), 109-119 (2010) doi: 10.2980/17-1-3310

7. T. Sullivan, D. Sullivan, P. Lindgren, Forest Ecology and Management 277, 180-195 (2012) doi: 10.1016/j.foreco.2012.03.037

8. E. Ivanter, Y. Kurkhinen, Biol. Bull. Russ. Acad. Sci. 43(4), 350-358 (2016) doi: 10.1134/S106235901604004X

9. A. Korosov A. Yakimova, E. Ivanter, Russian Journal of Ecology 46(1), 89-95 (2015) doi: 10.1134/S1067413615010063

10. R. Greene, R. Iglay, K. Evans, D. Miller, T. Wigley, S. Riffell, Forest Ecology and Management 360, 30-39 (2016) doi: 10.1016/j.foreco.2015.10.007 
11. V. Ilyashenko, E. Luchnikova, N. Skalon, I. Grebentschikov, A. Kovalevsky, IOP Conf. Ser.: Earth Environ. Sci. 224, 012055 (2019) doi:10.1088/1755$1315 / 224 / 1 / 012055$

12. E. Luchnikova, E. Bibik, N. Teplova, S. Onishchenko, V. Ilyashenko, Science Prospects 7(09), 10-13 (2010)

13. V. Ilyashenko, E. Luchnikova, Vestnik IrGSHA 83, 63-69 (2017) doi: 10.17238/issn1999-3765.2017.83

14. N. Chernousova, Contemp. Probl. Ecol. 3, 108-113 (2010) doi: 10.1134/S1995425510010170

15. J. Simonetti, A. Grez, C. Estades, Conservation Biology 27(5), 1117-1121 (2013) doi: 10.1111/cobi. 12129 